\title{
Effectiveness of Cognitive-Behavior Stress Management on Reducing Clinical Symptoms in Patients with Breast Cancer
}

\author{
Hamid Reza Jamilian ${ }^{1}$, Safoura Ghafouri-Asar ${ }^{2}$, Ahmad Bayat $^{3 *}$ \\ 1. Arak University of Medical Sciences, Arak, Iran \\ 2. Islamic Azad University, Hamedan, Iran \\ 3. Bu-Ali Sina University, Hamedan, Iran \\ Received: 26 May 2020 \\ Accepted for publication: 10 March 2021 \\ [EPub a head of print- 19 April 2021] \\ Payesh: 2021; 20 (2): 201-212
}

\begin{abstract}
Objective: Patients with breast cancer have symptoms of anxiety, depression and anxiety. This study was aimed to investigate the effectiveness of cognitive-behavioral stress management on the clinical symptoms among patients with breast cancer.

Methods: The was a quasi-experimental study with pre-test, post-test and follow up assessments. Twenty patients were randomly allocated into two groups: experimental group (10 patients) and control group (10 patients). Cognitive-behavioral stress management was administrated in 8 sessions for experimental group. The research instrument was SCL-90-R questionnaire. Data was analyzed by SPSS-25 software using repeated measure ANOVA.

Results: The results showed that cognitive-behavioral intervention led to reduction in clinical symptoms in some dimensions as measured by the SCL-90-R among patients in experimental group $(\mathrm{P}<0.05)$.

Conclusion: The findings indicated that the cognitive-behavioral stress management could reduce clinical symptoms of patients with breast cancer. Indeed, using cognitive-behavioral stress management in cancer treatment centers can be regarded as a complementary therapy alongside medical treatments.
\end{abstract}

Key Words: Cognitive-Behavior Stress Management, Clinical Symptoms, Breast Cancer

\footnotetext{
* Corresponding author: Bu-Ali Sina University, Hamedan, Iran

E-mail: bayata61@yahoo.com
} 


\title{
اثربخشى مديريت استرس شناختى - رفتارى بر كاهش نشانهایى بالينى بيماران مبتلا به سرطان بـتان
}

\author{
حميدرضا جميليان '، صفورا غفورى آثار ؟ّ، احمد بيات ب** \\ I. انشگاه علوم يزشكى اراك، اراك، ايران

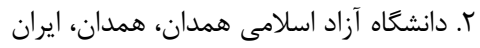

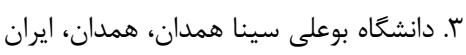

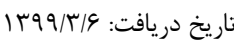

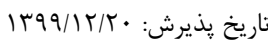

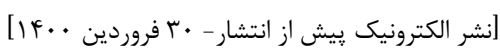

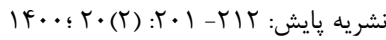

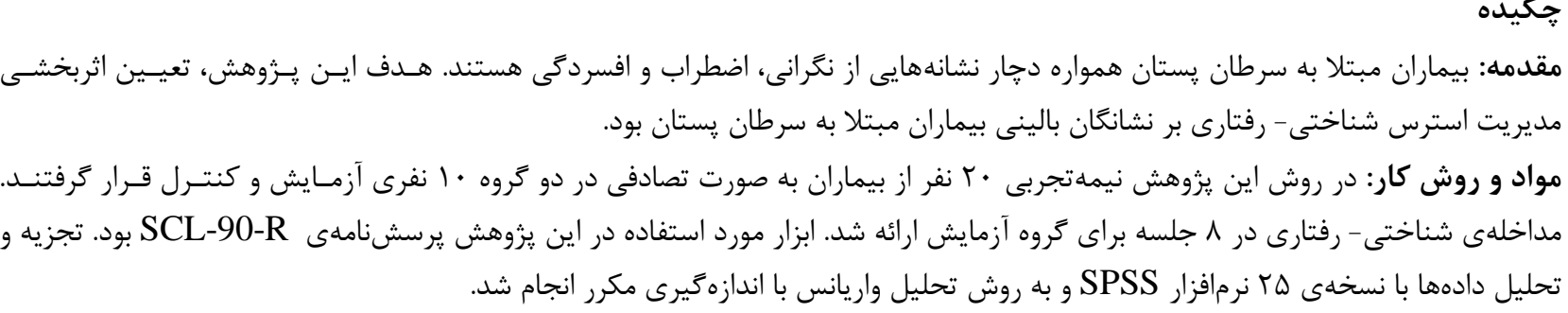

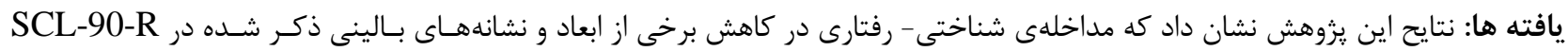

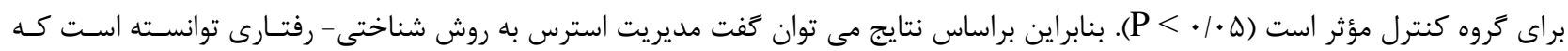

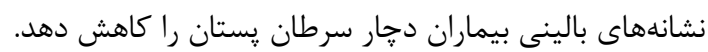

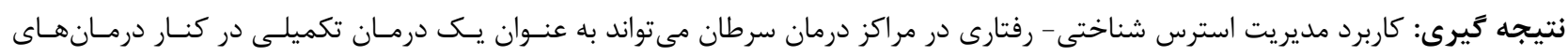

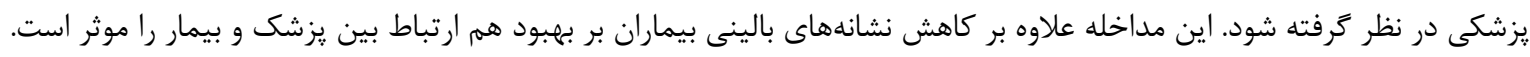

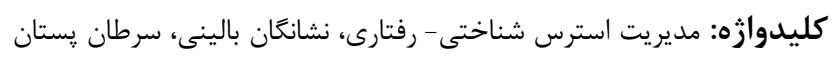

كد اخلاق: IR.AMSU.REC.1398.5543 
افسردَى، عدم اميد به زندگى، خود كشى، يرخاشكَرى، احساس كَناه

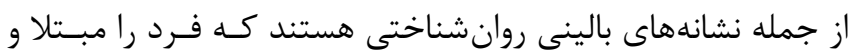

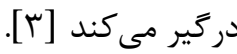
براى كاهش نشانههاى بالينى و بالا بردن كيفيت زندكى در بيمـاران

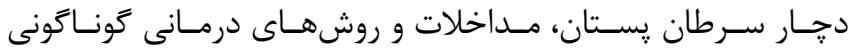

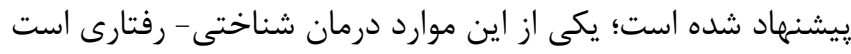
كه از دهلى • لو البراى درمان انواع بيماران مطرح و سودمندى آن آن

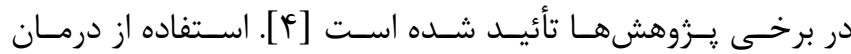

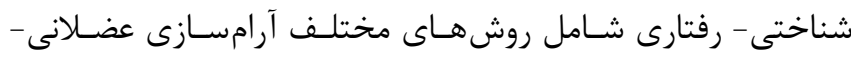

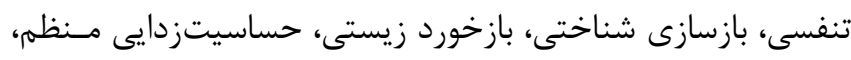

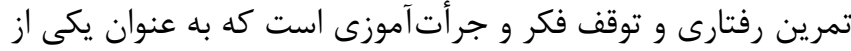

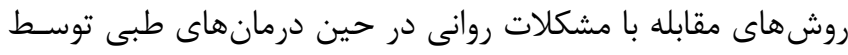

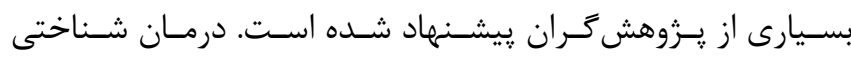

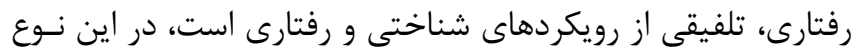

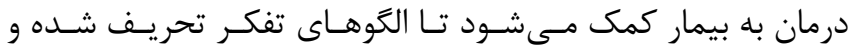

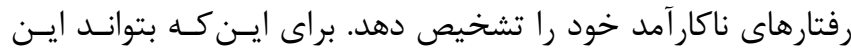

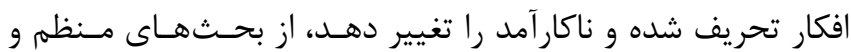
تكاليف رفتارى سازمان يافته استفاده مىشود. در زمينهى كنترل و يُيشكيرى از افزايش نشانههاى بالينى اقـدامات

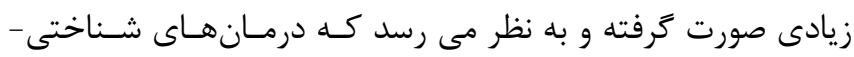

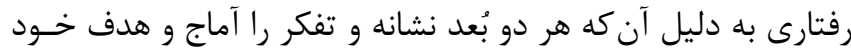

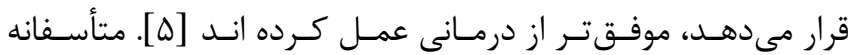

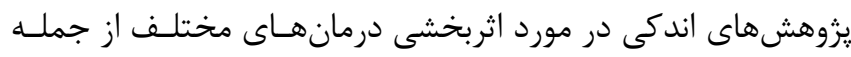

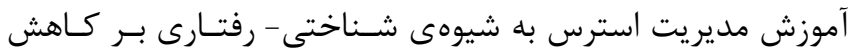

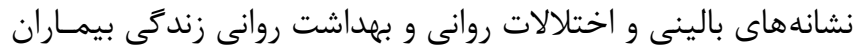

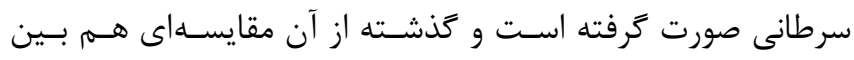

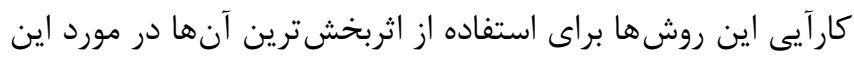

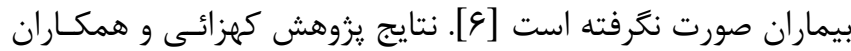

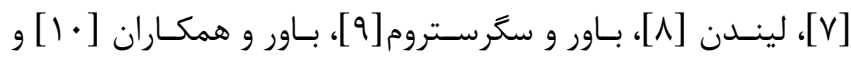

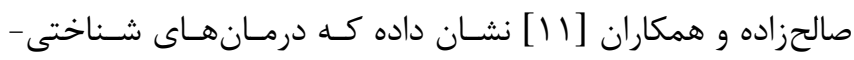

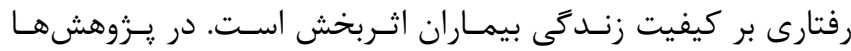

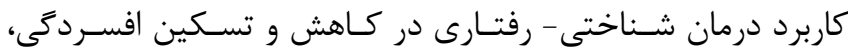

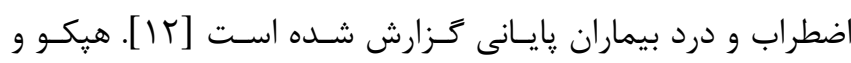
لجويز [T1 [1] عنوان مى كنند كه تعداد اين مداخلات بر روى بيمـاران

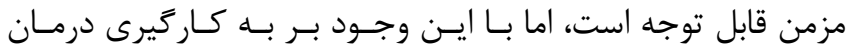

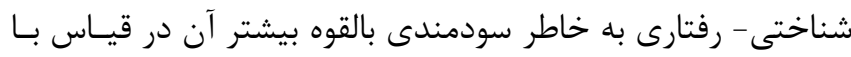

\section{مقدمه}

از آنجا كه سرطان يك بيمارى مـزمن و طاقـت فرسـا و در برخسى

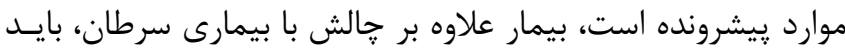

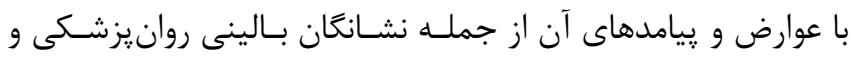

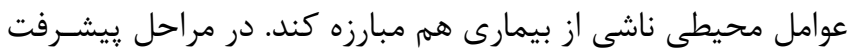
بيمارى، هر علامت تضعيفى بيـانكر كـاهش اسـتقلال بيمـار و زوال

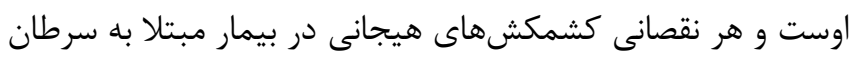

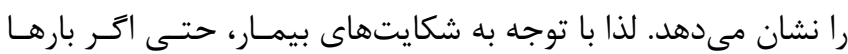

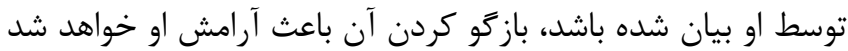

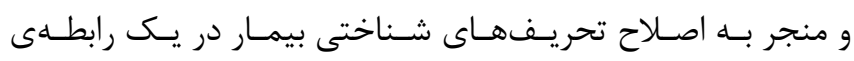

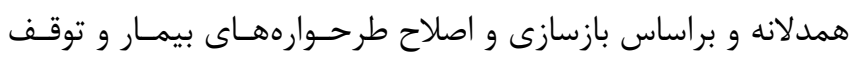
نشخوارهاى فكرى و فعال سازى رفتـارى مسىشـود و در عـين حسال

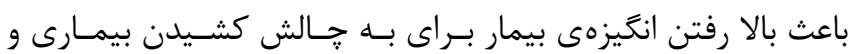

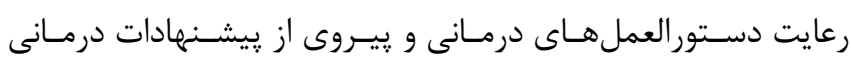

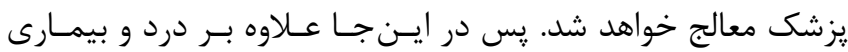

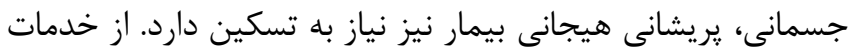

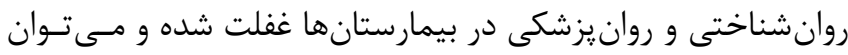

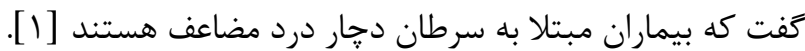

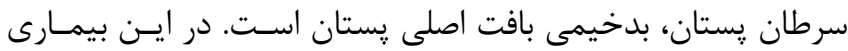

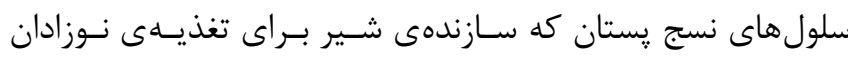

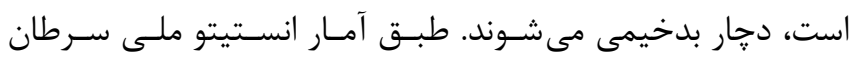

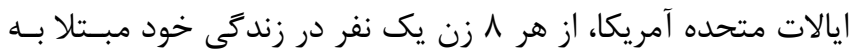

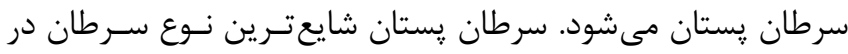

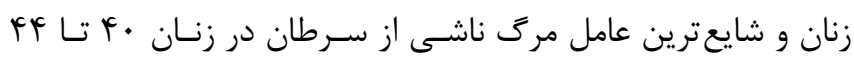

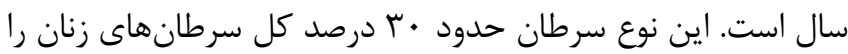

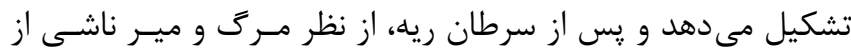

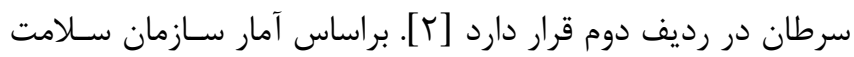

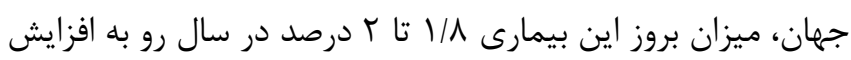
است. در كشور ما آمار دقيقى از شيوع اين بيمارى در دست دئ نيست با اين وجود يزوهشهاى انجام شده نشـان داده اسـت كـهـ در سـال

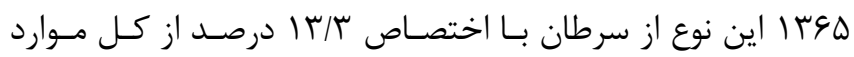

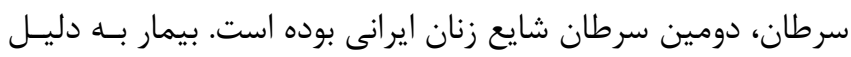

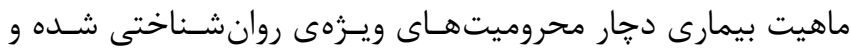

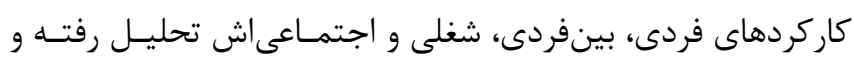

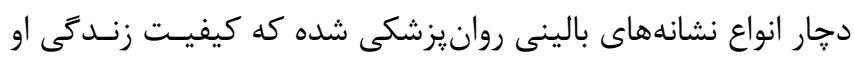

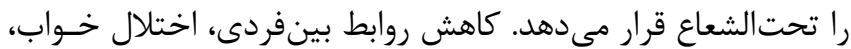


نفر از بيماران دجار سرطان يستان به صورت تصادفى ساده انتخـاب

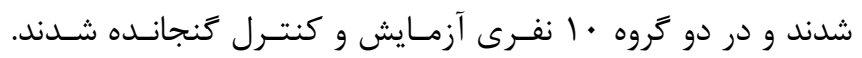

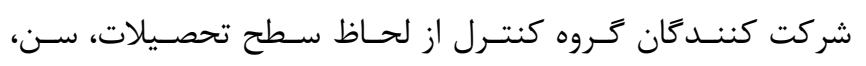

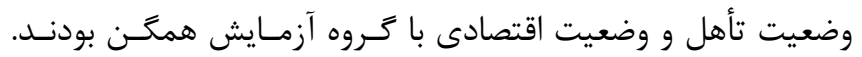
براى درنظر داشتن عدم اثريذيرى گروه كنترل از شرايط مداخلـهاى

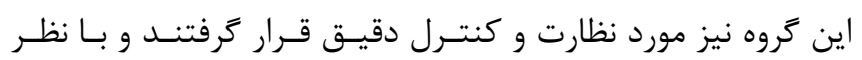

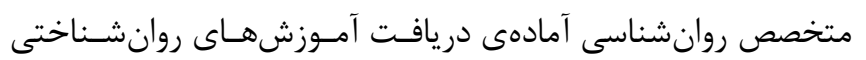

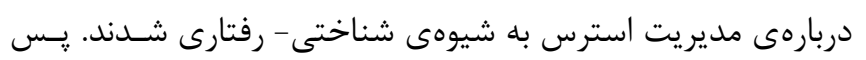

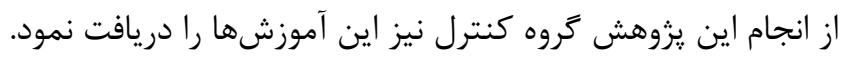

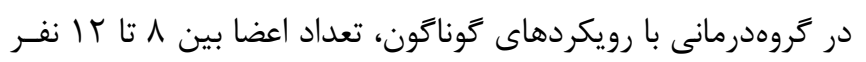

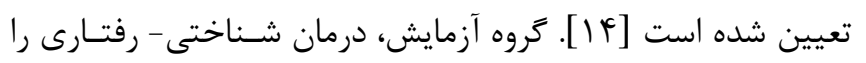

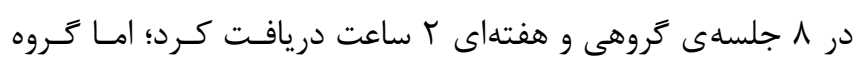

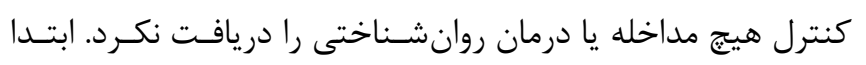

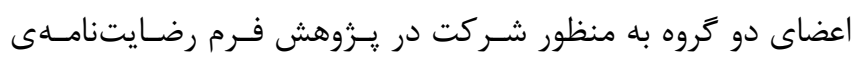

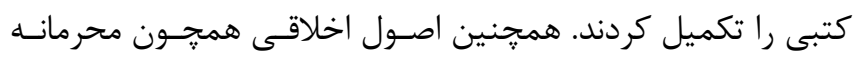

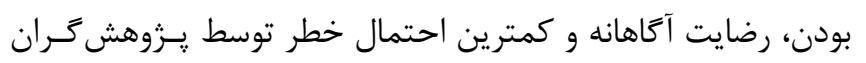

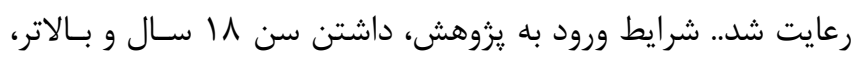

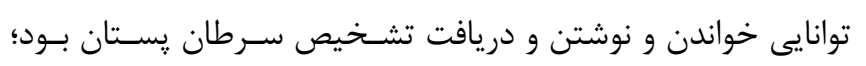

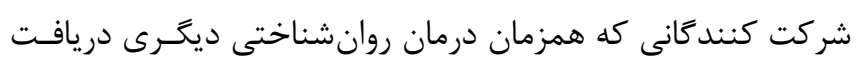

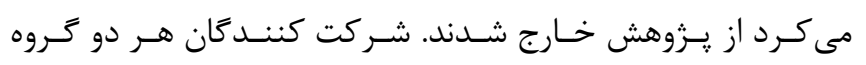

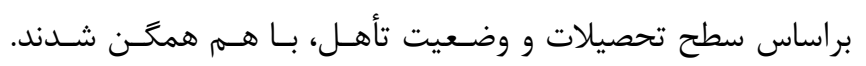

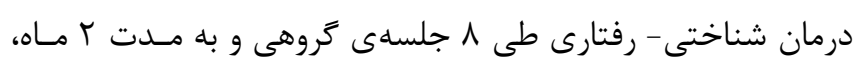

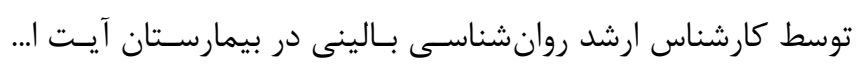

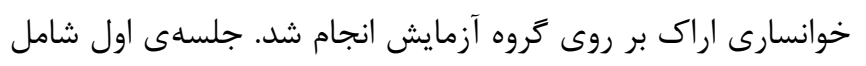

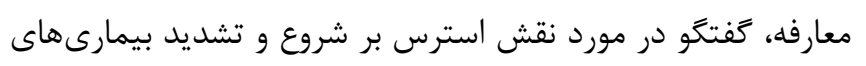

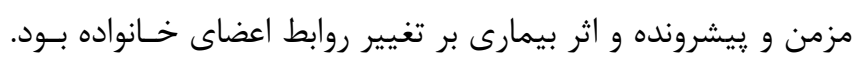

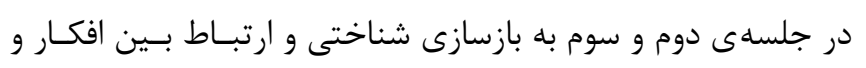

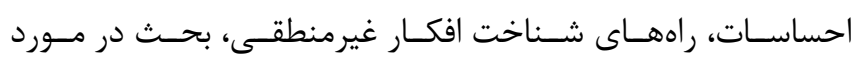

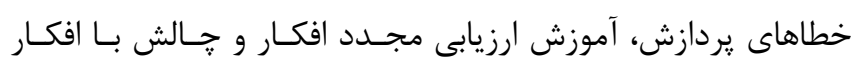

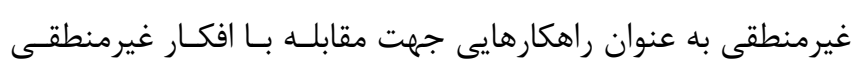

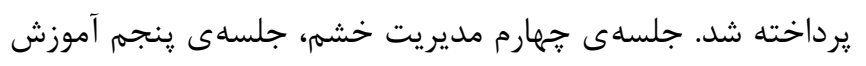

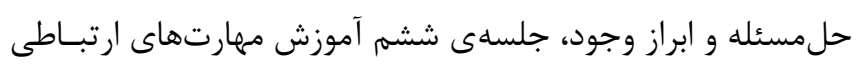

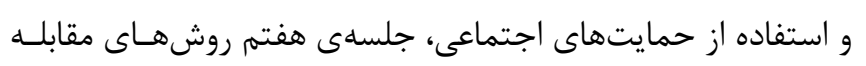

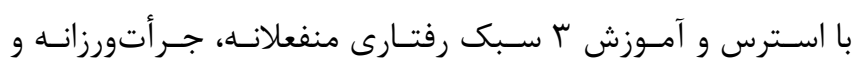

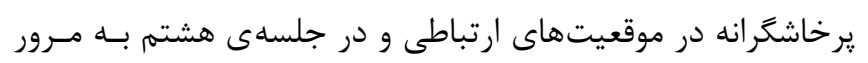

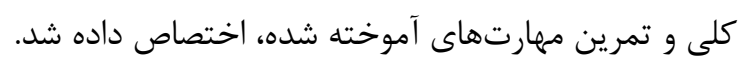

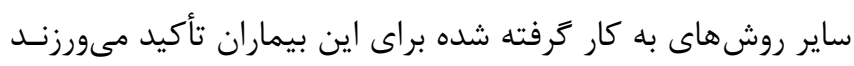

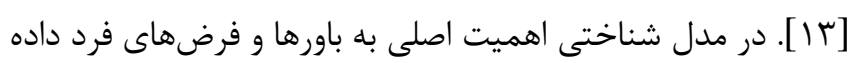

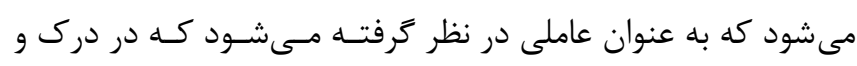

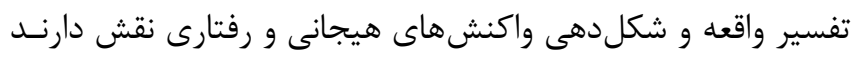

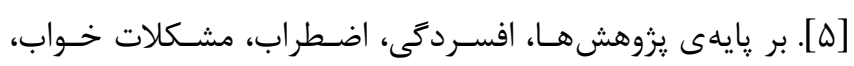

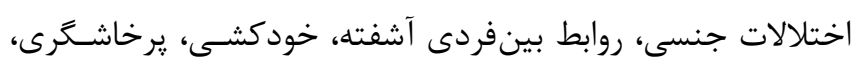

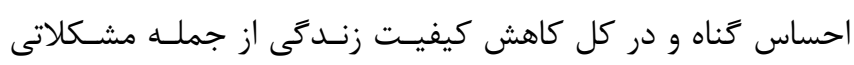

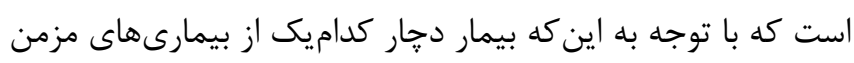

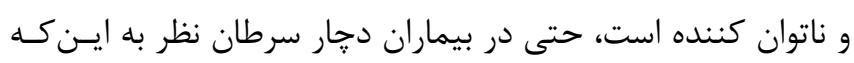

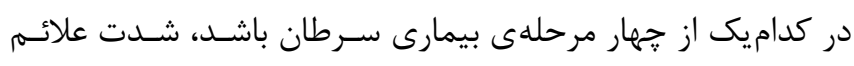

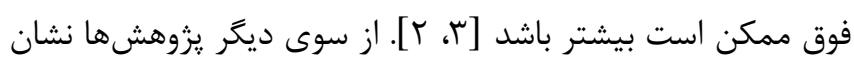

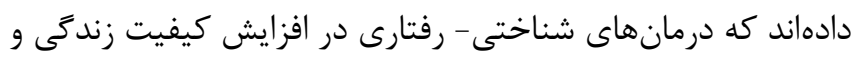

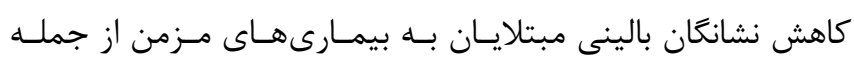

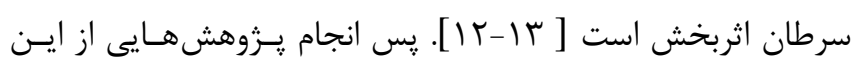

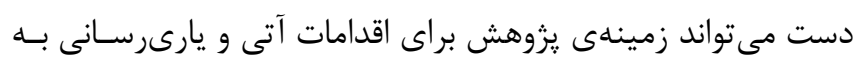

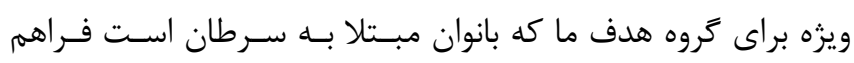

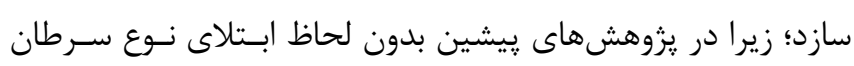

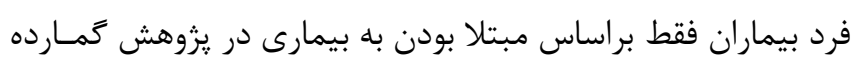

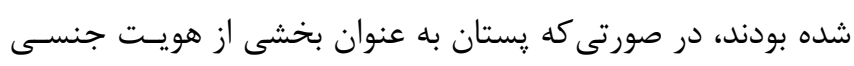

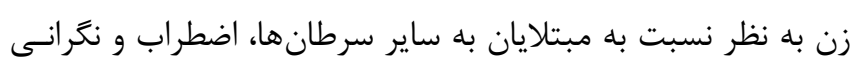

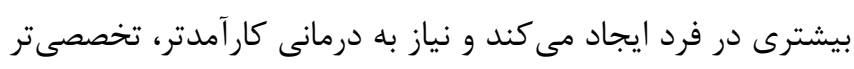

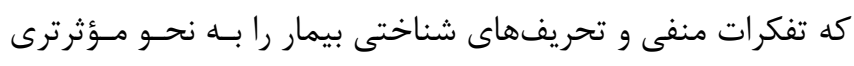

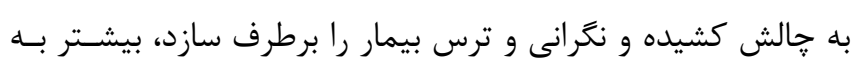

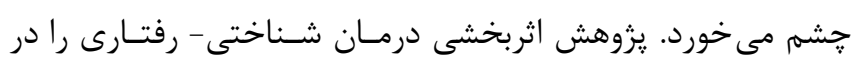

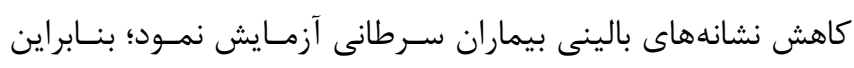

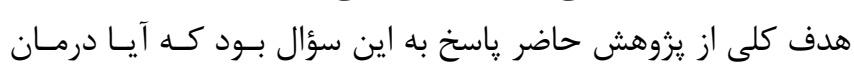

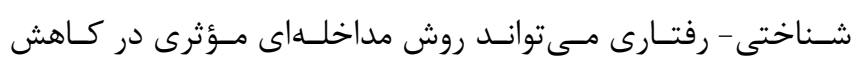
نشانهاى بالينى بيماران سرطانى باشد يا خير؟

\section{مواد و روش كار}

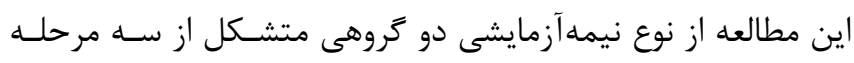

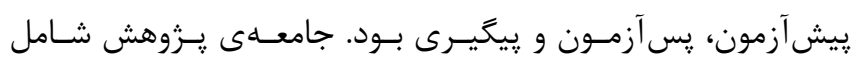

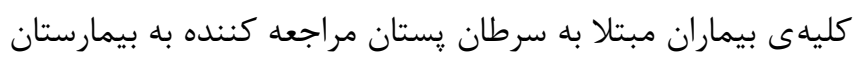

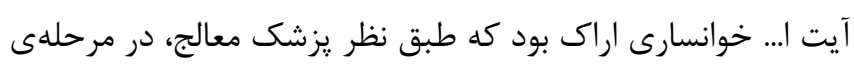

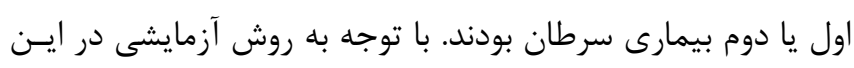

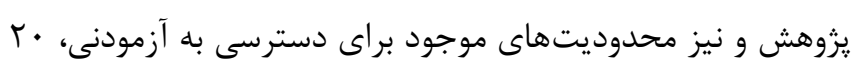


شناختى - رفتارى، مداخلهاى بركرفتـهـ از راهنمـاى عملـى مـديريت

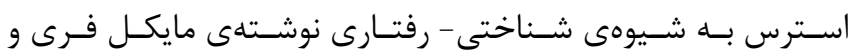

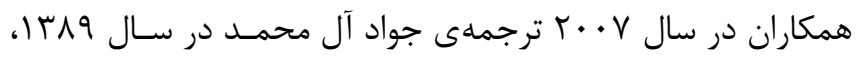

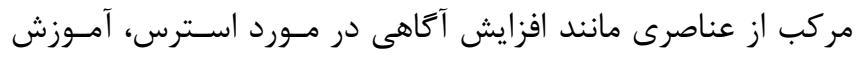

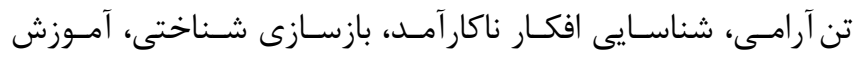

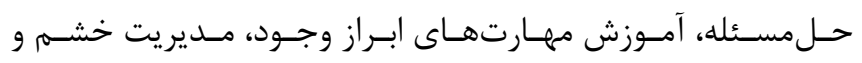

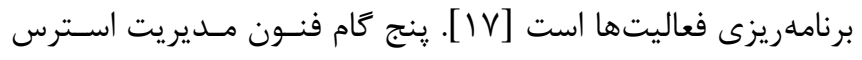

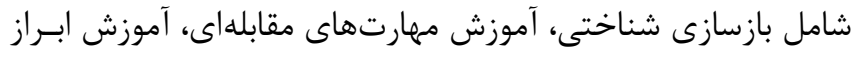

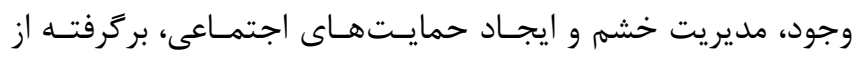

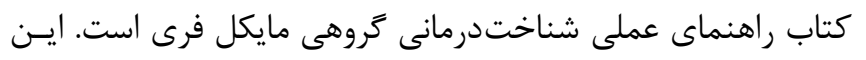

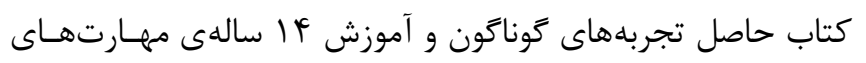

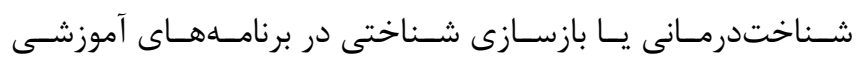

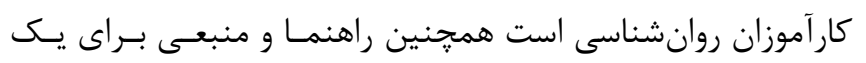

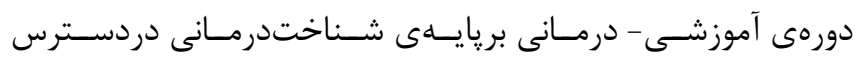

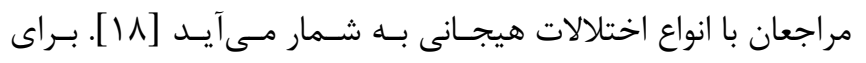

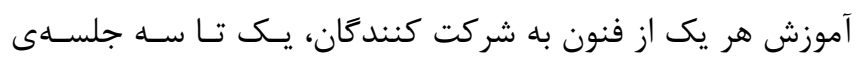

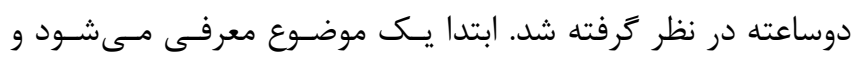

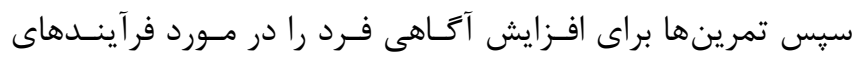

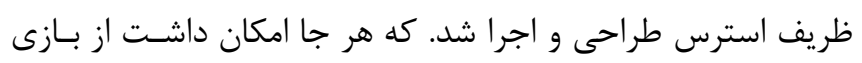

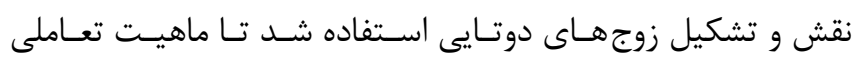

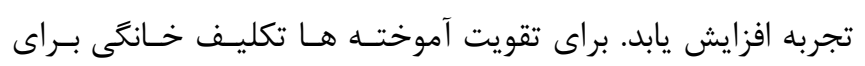

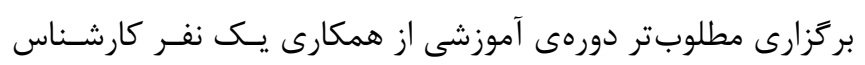

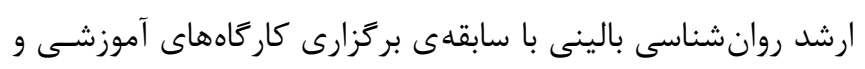

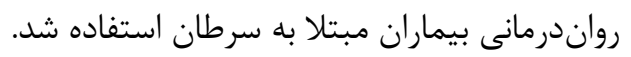

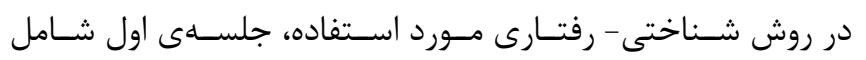

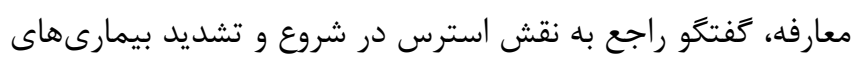

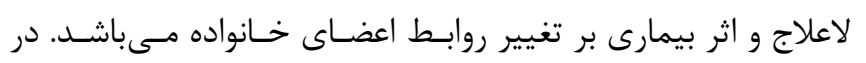

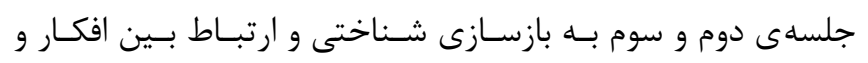

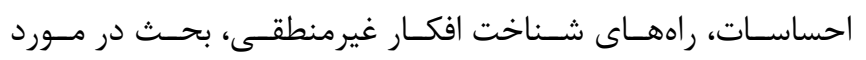

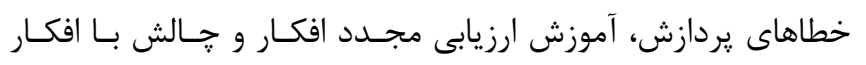

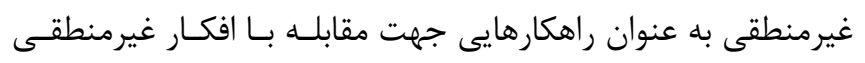

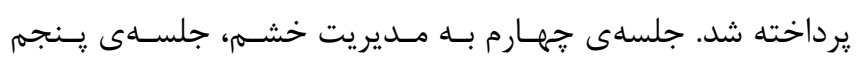

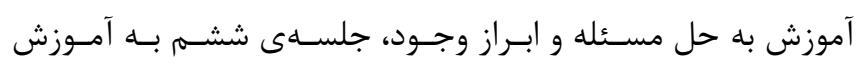

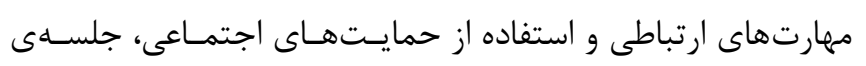

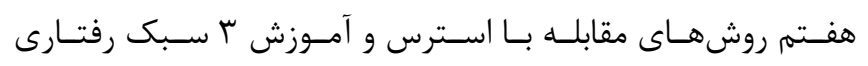

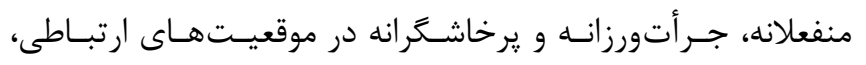

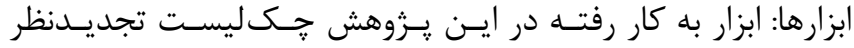

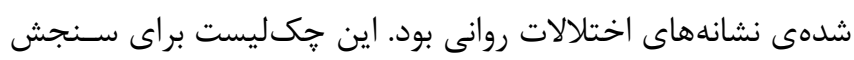

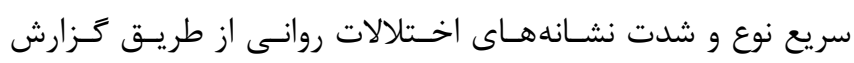

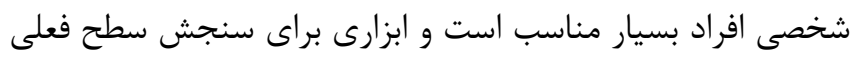

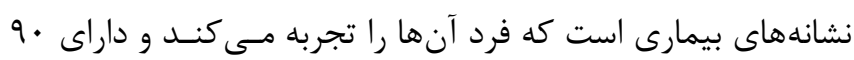

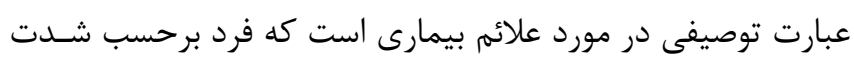

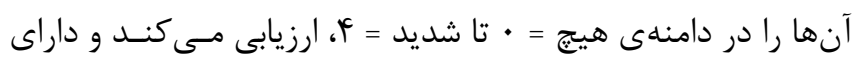

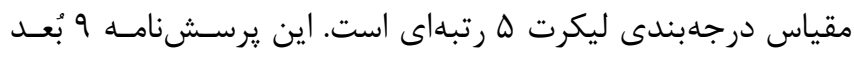

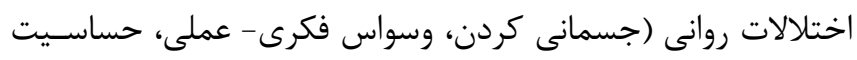

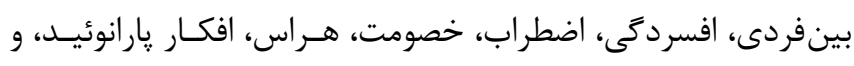

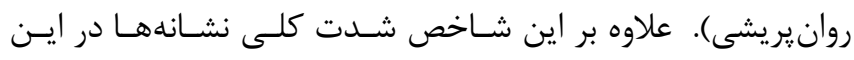

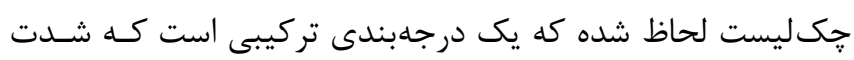

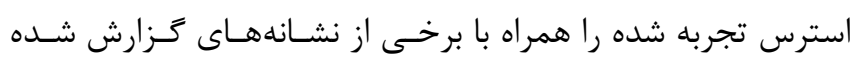

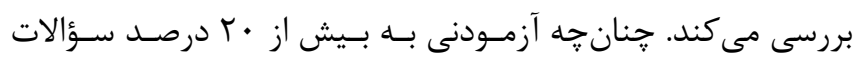

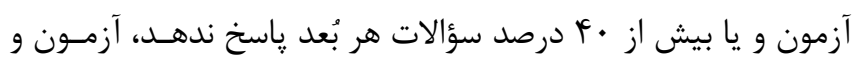

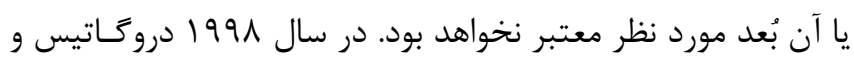

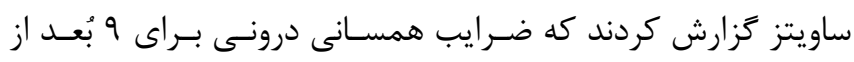

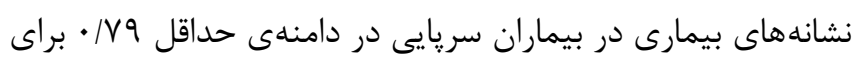

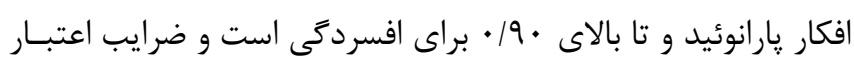

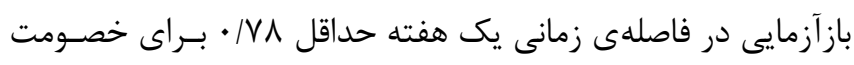

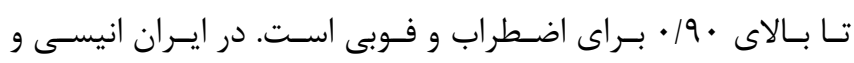

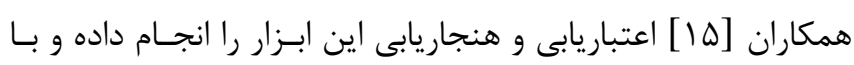

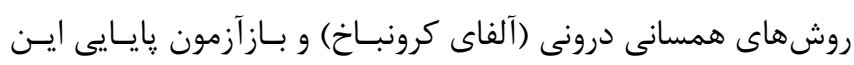

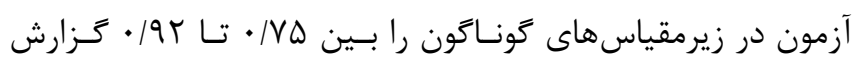

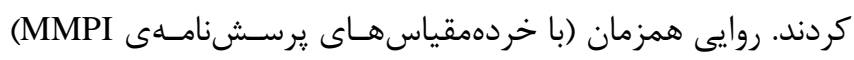

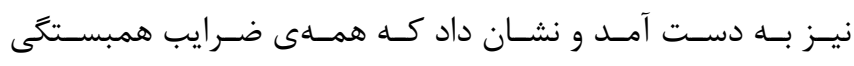

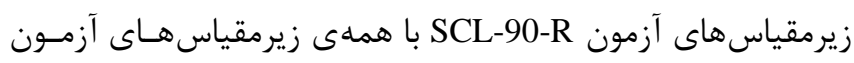
MMPI

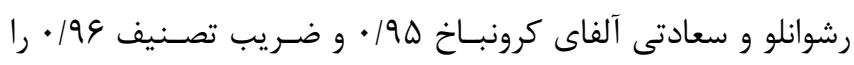

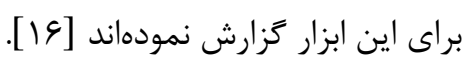

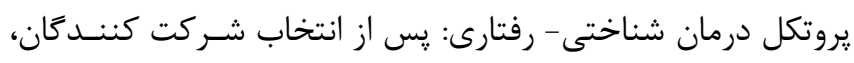

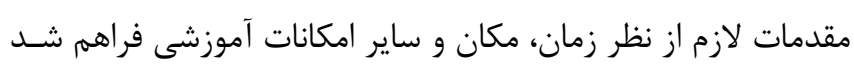

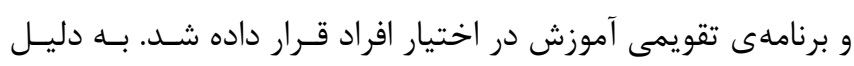

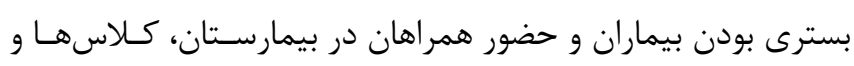

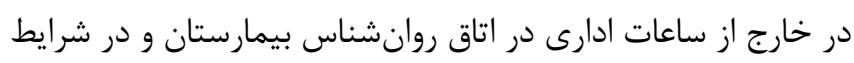

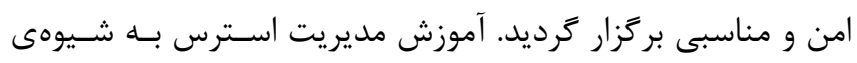


يارانوئيد در ابتدا و پايان مداخله در هـر دو گَروه يكسـان بـود و در

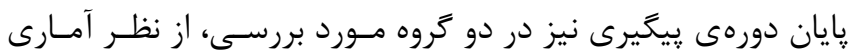

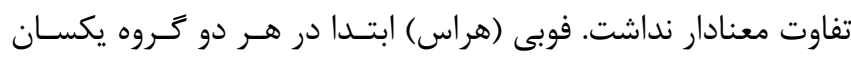

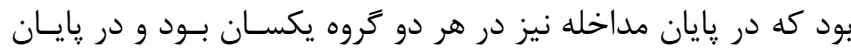

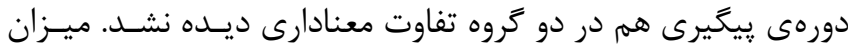

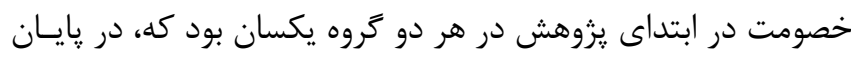

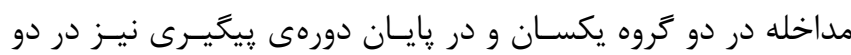

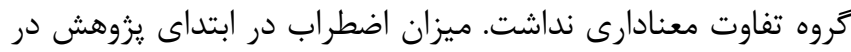

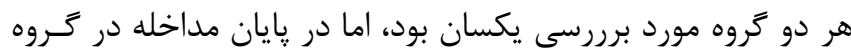

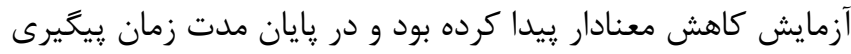

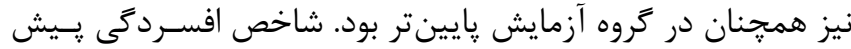

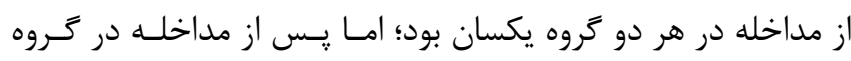

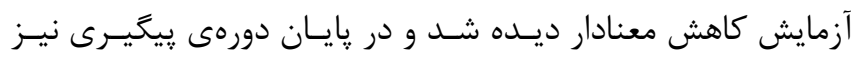

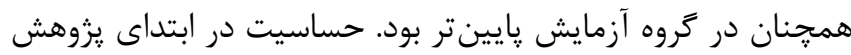

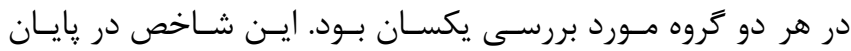

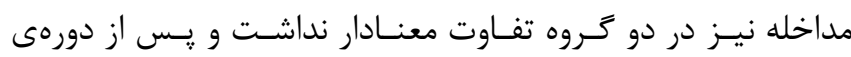

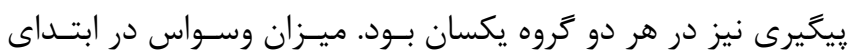

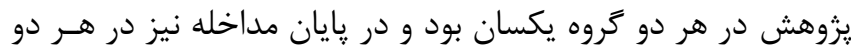

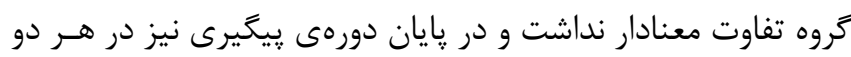

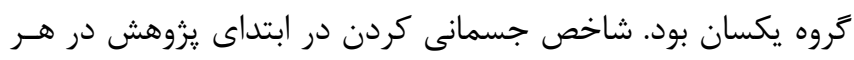

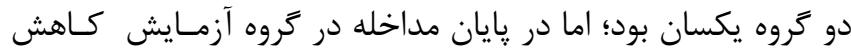

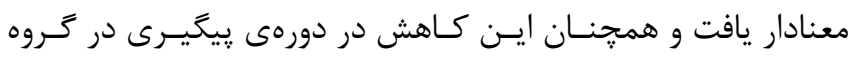

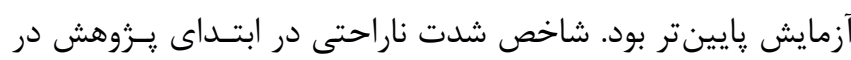

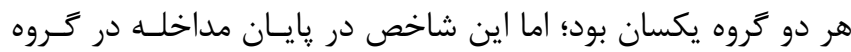

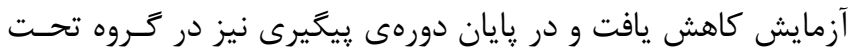
آزمايش و مداخله يايينتر بود.
جلسهى هشـتم مـرور كلـى و تمـرين مهـارتهـاى آموختـهـ شـده، اختصاص داده شد. طى برنامه دو رهبر تروه به عنوان الكوهاى نقاى نقش

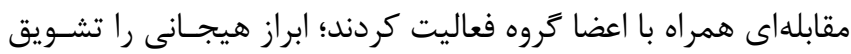

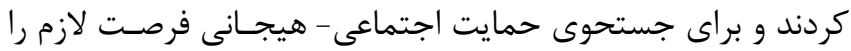

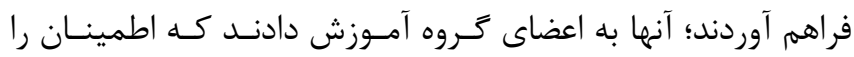

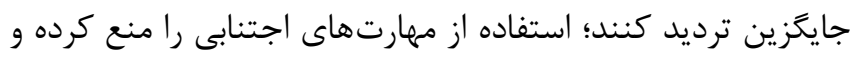

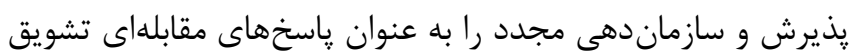

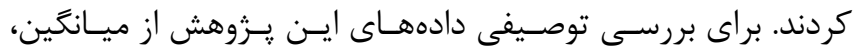

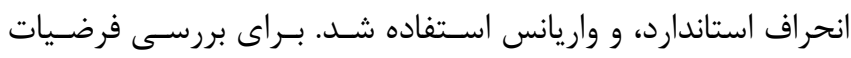

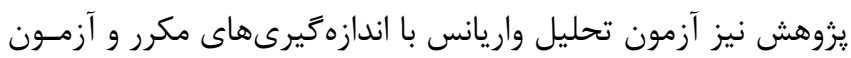

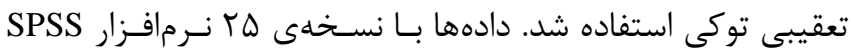

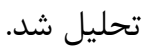

\section{بافتهها}

در ابتداى يزوهش دو كروه مورد برداف برسى از نظر سن، وضعيت تأهل و

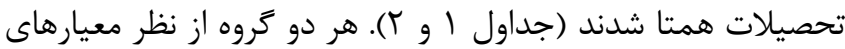

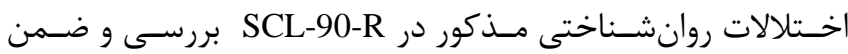

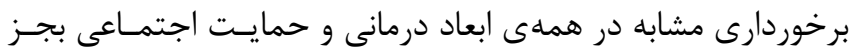

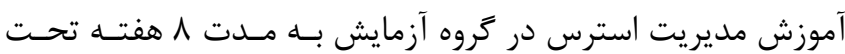

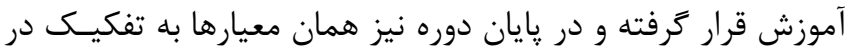

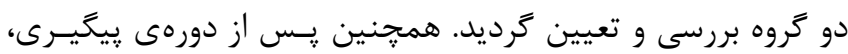

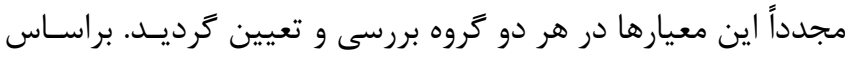

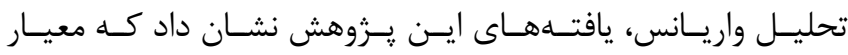

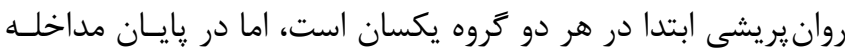

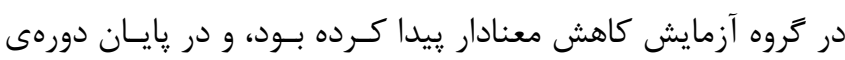

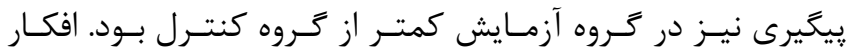

\begin{tabular}{|c|c|c|c|c|}
\hline معنادارى & كروه كنترل & كروه آزمايش & & \\
\hline \multirow{3}{*}{$\cdot 1 \cdot \cdot 1$} & 9 & 4 & متأهل & \multirow{3}{*}{ وضعيت تأهل } \\
\hline & $r$ & r & مجرد & \\
\hline & r & r & ساير & \\
\hline \multirow{4}{*}{.. .1} & r & r & ابتدايى & \multirow{4}{*}{ تحصيلات } \\
\hline & 1 & 1 & راهنمايى & \\
\hline & r & r & متوسطه & \\
\hline & r & f & دانشَاهى & \\
\hline
\end{tabular}


سال بيستم، شماره دوم، فروردين - ارديبهشت ... س

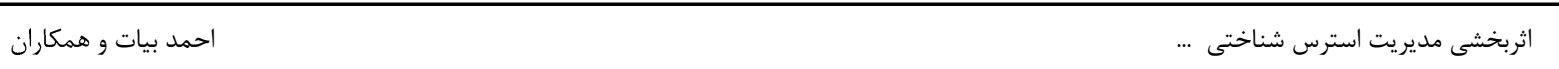

جدول ז: ميانگَين و انحراف معيار سن در دو كروه مورد بررسى

\begin{tabular}{|c|c|c|c|c|c|c|}
\hline معنادارى & $\mathrm{t}$ & درجه آزادى & انحراف معيار & ميانگَين & تعداد & \\
\hline $.1 \cdot 1$ & $.1 \cdot 1$ & 11 & $9 / 99$ & TE/G & 1. & آزمايش \\
\hline$\cdot 1 \cdot \cdots 1$ & $\cdot 1 \cdot \cdot 1$ & 11 & $9 / 90$ & re/9 & 1. & كنترل \\
\hline
\end{tabular}

جدول ب: مقايسهى ميانگين و انحر اف معيار شاخصهاى سلامت روان به تفكيك زمان سنجش در هر دو تروه مورد بررسى

\begin{tabular}{|c|c|c|c|c|c|c|c|}
\hline معنادارى & $\mathrm{F}$ & انحراف معيار & ميانگين & تعداد & كروه & مرحله & \\
\hline \multirow{2}{*}{$\cdot$ llfF } & \multirow{2}{*}{ ( אس/ץ } & $\cdot / r V$ & $1 / \pi 1$ & 1. & آزمايش & \multirow{2}{*}{ پِيش از مداخله } & \multirow{6}{*}{ روانيريشى } \\
\hline & & $\cdot \pi$ & $1 / \Delta 9$ & 1. & كنترل & & \\
\hline \multirow{2}{*}{$\cdot 1 \cdot \cdot 1$} & \multirow{2}{*}{$1 / 10$} & $\cdot / 1 \mathrm{~V}$ & $1 / 11$ & 1. & آزمايش & \multirow{2}{*}{ ِّ از مداخله } & \\
\hline & & $\cdot \pi v$ & $1 / 94$ & 1. & كنترل & & \\
\hline \multirow{2}{*}{$\cdot / \cdot 1$} & \multirow{2}{*}{ N/Tr } & $\cdot \pi r$ & $1 / T \Lambda$ & 1. & آزمايش & \multirow{2}{*}{ دور0ى پِيخيرى } & \\
\hline & & $\cdot / r F$ & $1 / V V$ & 1. & كنترل & & \\
\hline \multirow{2}{*}{. /NIT } & \multirow{2}{*}{$\cdot 10 \Lambda$} & .19 & $1 / 91$ & 1. & آزمايش & \multirow{2}{*}{ پِيش از مداخله } & \multirow{6}{*}{ افكار يارانوئيد } \\
\hline & & $\cdot / \Delta V$ & $1 / A F$ & 1. & كنترل & & \\
\hline \multirow{2}{*}{$\cdot / r \cdot$} & \multirow{2}{*}{$1 / \sqrt{ } 4$} & . & $1 / 01$ & 1. & آزمايش & \multirow{2}{*}{ ِّ از مداخله } & \\
\hline & & $\cdot \mid \Delta F$ & $1 / \lambda$ & 1. & كنترل & & \\
\hline \multirow{2}{*}{$\cdot / V \& V$} & \multirow{2}{*}{$\cdot / 1 \cdot \Lambda$} & $\cdot 148$ & I/VF & 1. & آزمايش & \multirow[b]{2}{*}{ دورهى پِيخيرى } & \\
\hline & & $\cdot \mid \pi /$ & $1 / 29$ & 1. & كنترل & & \\
\hline \multirow{2}{*}{$\cdot / 9 \cdot \Delta$} & \multirow{2}{*}{$.1 \cdot 10$} & .119 & .194 & 1. & آزمايش & \multirow{2}{*}{ يِيش از مداخله } & \\
\hline & & $\cdot|r|$ & $\cdot 19 \mathrm{~V}$ & 1. & كنترل & & \\
\hline ( & $.1 \cdot 19$ & .119 & $\cdot \operatorname{lar}$ & 1. & آزمايش & س ساز مداخله & هـ اس \\
\hline & 0.11 & $\cdot / 1 \mathrm{~V}$ & $\cdot \operatorname{lar}$ & 1. & كنترل & "ِس ار مداحله & هراس - ماس \\
\hline$\cdot 1 \cdot 1 \varepsilon$ & r & $\cdot / 1 \mathrm{~F}$ & $\cdot / 4 \Delta$ & 1. & آزمايش & & \\
\hline • & $1 \pi \cdot v$ & .119 & $\cdot 10$ & 1. & كنترل & دور0ى پِيليرى & \\
\hline . LAST & . /req & $\cdot / \Delta V$ & $1 / 49$ & 1. & آزمايش & بش لان مداخله & \\
\hline . $\mid$ Q & $\cdot 1117$ & $\cdot / \Lambda F$ & $1 / 4 \pi$ & 1. & كنترل & "ِيnى 'ر مداحله & \\
\hline.$/ 10 \mathrm{r}$ & .194 & $\cdot \pi \Delta$ & $1 / 11$ & 1. & آزمايش & يس ان مداخله & \\
\hline •/NAT & $\cdot 14 T$ & $\cdot \mid \mathrm{AM}$ & $1 / Q F$ & 1. & كنترل & يَ آز مداحله & حصومت \\
\hline $.1 . \varepsilon 9$ &.$/ V \varepsilon^{c}$ & ת & $1 / 10$ & 1. & آزمايش & & \\
\hline$\cdot 1.44$ & - MT & $\cdot / V F$ & $1 / 90$ & 1. & كنترل & دور0ى پِيكيرى & \\
\hline - &.$/ 8 e^{r}$ & $\cdot / V \Delta$ & T/Fe & 1. & آزمايش & بش لان مداخله & \\
\hline & & $1 / \cdot r$ & $r / D Q$ & 1. & كنترل & 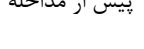 & \\
\hline .1 .1 & $r \cdot \mu$ & - & $1 / r$ & 1. & آزمايش & يس ان مداخله & \\
\hline$\cdot \cdots 1$ & $T \cdot / T$ & $\cdot / V \wedge$ & T/AF & 1. & كنترل & ״ِ آز مداحله & اضطراب \\
\hline.$\cdots r$ & J/ar & $\cdot|f|$ & $1 / \Delta 9$ & 1. & آزمايش & & \\
\hline & $11 / 01$ & . IAr & r/GY & 1. & كنترل & دورهى پي يحيرى & \\
\hline.$/ V \mu^{\prime}$ & .1119 & .109 & T/MF & 1. & آزمايش & لمث لن مباخله & \\
\hline & .1117 & $\cdot 199$ & T/TF & 1. & كنترل & קֶيس از مداحله & \\
\hline...$r$ & GNG & $\cdot / 4 q$ & $1 / r F$ & 1. & آزمايش & سـ ان مداخله & \\
\hline$\cdot \cdots 1$ & $7 \mathrm{~N} / 7$ & $\cdot / r V$ & T/VF & 1. & كنترل & ״ِ آز مداحله & اقسردنى | ل \\
\hline.$(\cdots)$ & ع & $\cdot 148$ & $1 / 94$ & 1. & آزمايش & & \\
\hline$\cdot \cdots 1$ & $71 / 4$ & . $/ T r$ & $r / 91$ & 1. & كنترل & دورهى پِيليرى & \\
\hline.$/ \varepsilon y \in$ & $.11 \cdot 1$ & $.19 \mathrm{~V}$ & $1 / V T$ & 1. & آزمايش & 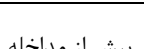 & \\
\hline . Tht & $\cdot n \cdot \wedge$ & $\cdot / V T$ & I/Ar & 1. & كنترل & 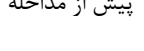 & \\
\hline .1 res & L. & .149 & $1 / T V$ & 1. & آزمايش & ليس ان مداخله & حساسـت \\
\hline$\cdot 117 \lambda$ & $111 \cdot$ & . & $1 / 90$ & 1. & كنترل & "ِ آز مداحله & حساسيت \\
\hline . $\& \Delta \Delta$ &.$(\Delta \Delta \mathrm{F}$ & .198 & $1 / 91$ & 1. & آزمايش & & \\
\hline$\cdot \pi \omega \omega$ & $\cdot|\Delta \lambda|$ & . 194 & 1/Ar & 1. & كنترل & دورهى بياليرى & \\
\hline . V(Y) & $.11 \cdot f$ & $\cdot|\Delta|$ & $1 / V 1$ & 1. & آزمايش & بث 1. مراخلي & (a) \\
\hline$\cdot|V| \omega \mid$ & $\cdot 11 \cdot T$ & $\cdot \mid \Delta r$ & $1 / 94$ & 1. & كنترل & رِيش از مداحله & \\
\hline
\end{tabular}




\begin{tabular}{|c|c|c|c|c|c|c|c|}
\hline \multirow{2}{*}{$\cdot|\Delta| f$} & \multirow{2}{*}{. } & $\cdot / 49$ & $1 / 4 \wedge$ & 1. & آزمايش & \multirow{2}{*}{ پِ از مداخله } & \\
\hline & & . & $1 / \Delta 9$ & 1. & كنترل & & \\
\hline \multirow{2}{*}{$\cdot / 4 \cdot 9$} & \multirow{2}{*}{ - VTr } & זr/. & $1 / N r$ & 1. & آزمايش & \multirow{2}{*}{ دورهى بيخيرى } & \\
\hline & & $\cdot|\Delta|$ & $1 / \Delta V$ & 1. & كنترل & & \\
\hline \multirow{2}{*}{$\cdot / \wedge \Delta 9$} & \multirow{2}{*}{ זr/. } &.$/ 91$ & $T / 4)$ & 1. & آزمايش & \multirow{2}{*}{ پِيش از مداخله } & \multirow{6}{*}{ جسمانى كردن } \\
\hline & &.$/ 9 T$ & $r / 4 A$ & 1. & كنترل & & \\
\hline \multirow{2}{*}{ •..r } & \multirow{2}{*}{$r r / \Delta)$} & rז/. & $1 / 4 T$ & 1. & آزمايش & \multirow{2}{*}{ يس از مداخله } & \\
\hline & & $\cdot / \wedge V$ & t/AT & 1. & كنترل & & \\
\hline \multirow{2}{*}{$\cdot 1 . \cdot 1$} & \multirow{2}{*}{$r T / \cdot 1$} & $\cdot \mid F F$ & $1 / 09$ & 1. & آزمايش & \multirow{2}{*}{ دورهى پيخيرى } & \\
\hline & & . NT & r/AS & 1. & كنترل & & \\
\hline \multirow{2}{*}{$\cdot|\lambda|$} & \multirow{2}{*}{.$/ 1 T$} & $\cdot / 4 \wedge$ & $T / . r$ & 1. & آزمايش & \multirow{2}{*}{ ييش از مداخله } & \multirow{6}{*}{ شدت ناراحتى } \\
\hline & & $\cdot / r v$ & 1/99 & 1. & كنترل & & \\
\hline \multirow[t]{2}{*}{$\cdot 1 . .1$} & \multirow[t]{2}{*}{$r \mid / r$} & r & $1 / 4 T$ & 1. & آزمايش & \multirow{2}{*}{ پِ از مداخله } & \\
\hline & & . & $r / T)$ & 1. & كنترل & & \\
\hline \multirow{2}{*}{$\cdot 1 . .1$} & \multirow{2}{*}{$r q / 9$} & $\cdot \pi \Delta$ & $1 / 09$ & 1. & آزمايش & \multirow{2}{*}{ دورهى بيخيرى } & \\
\hline & & سז/• & $T / F \Delta$ & 1. & كنترل & & \\
\hline
\end{tabular}

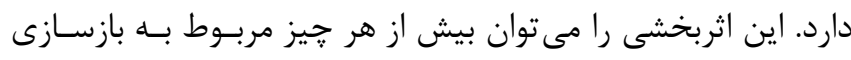

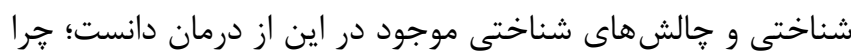

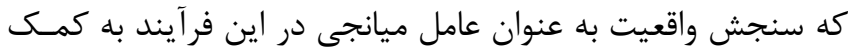

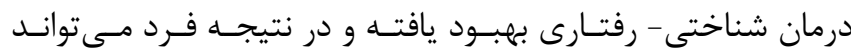

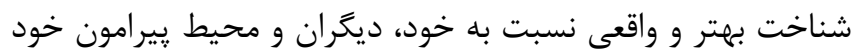

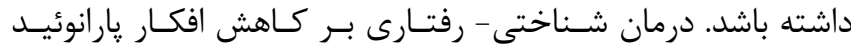

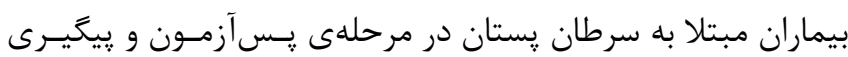

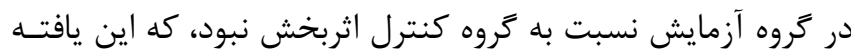

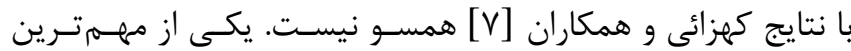

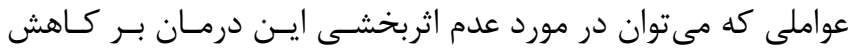

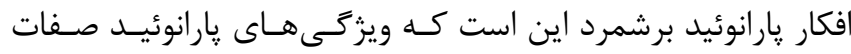

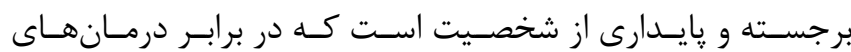

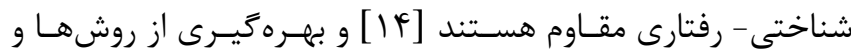

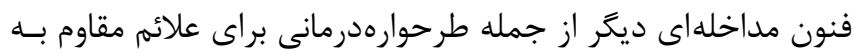
درمان هاى شناختى كه با سازههاى شخصيتى فرد بيوند خوردهانسا،

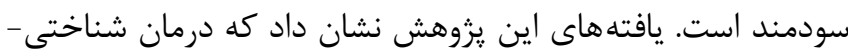

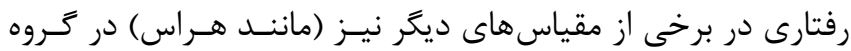

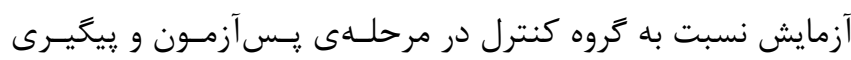

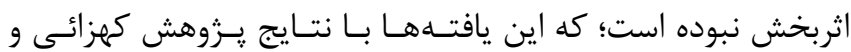
همكاران [V] در رابطه با اثربخشى اين درمان بر كاهش علائم فوبيـا

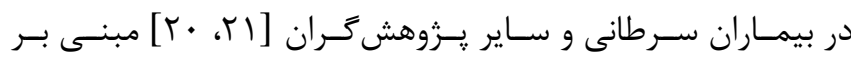

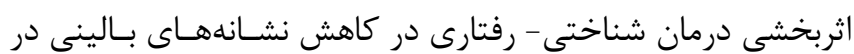

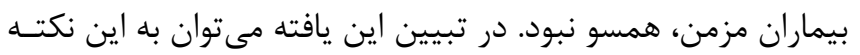

\section{بحث و نتيجه گيرى}

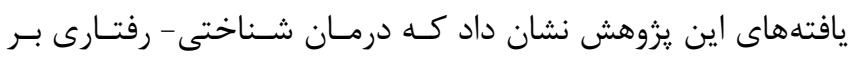

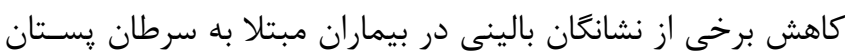

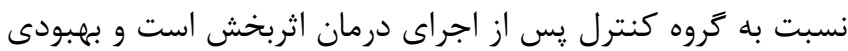

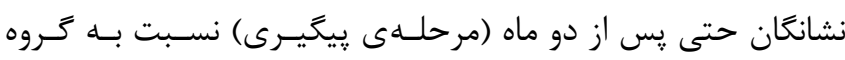

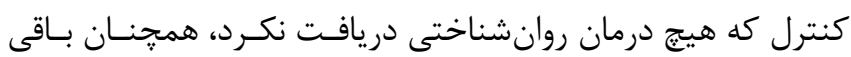

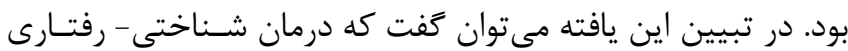

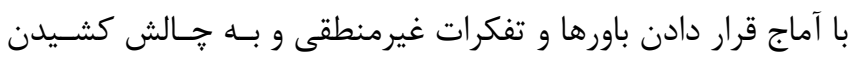

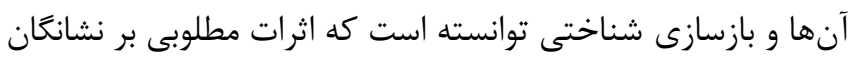

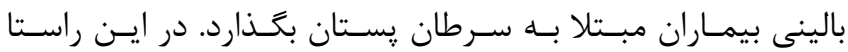

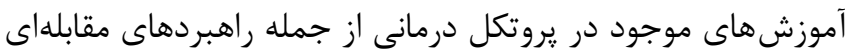

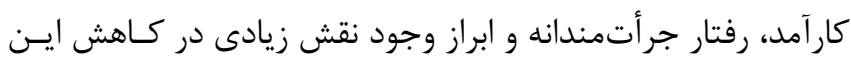

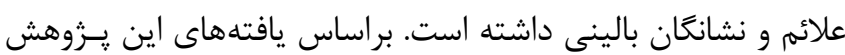
درمان شناختى - رفتارى منجر به كاهش علائم روانيريشى در كروه

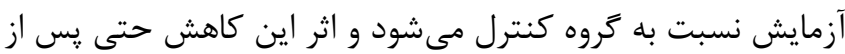

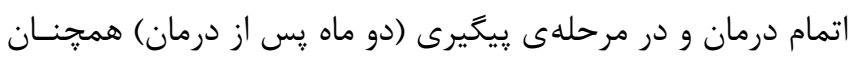
نسبت به كروه كنترل كه هيج تغييرى را كزارش نكردنـد، همجنـان

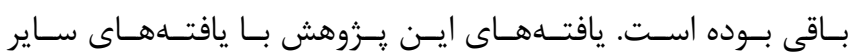

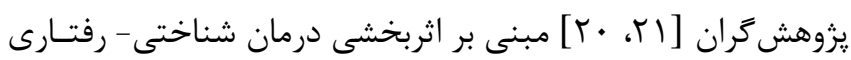

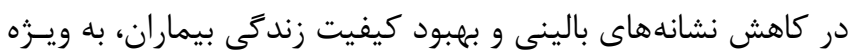

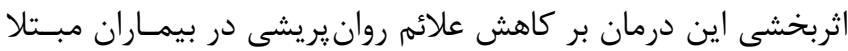

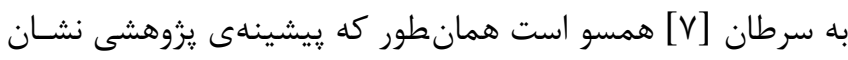

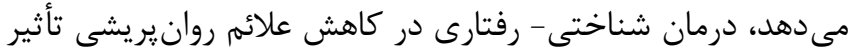




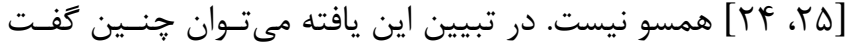
كه براى كاهش نشانههاى بالينى وسواس - اجبار به عنـوان اختلالى

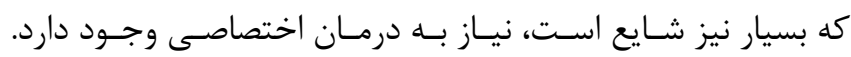
وسواس به سادكى قابل درمان نيست و حتى كاهش علائم آن نيز به آنس

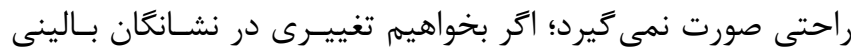

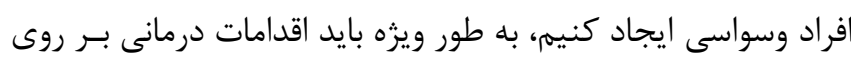

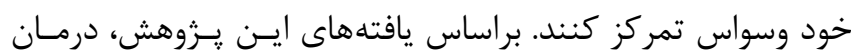
شناختى - رفتارى بر كاهش علائم جسمانى كردن در بيماران مبـتلان آنان

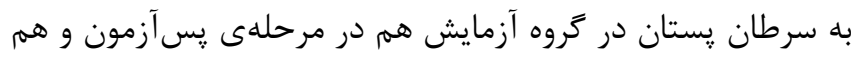

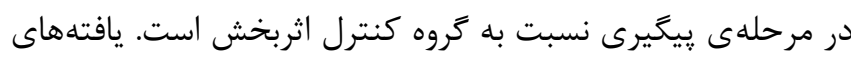

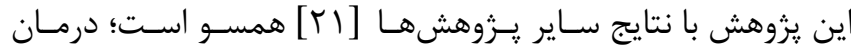

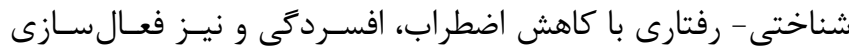

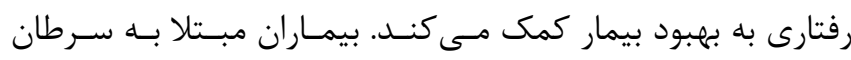

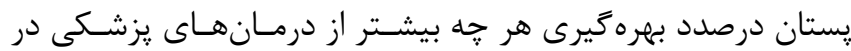

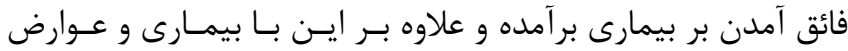

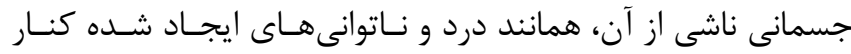

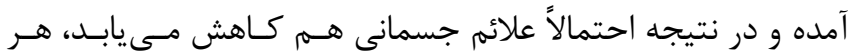

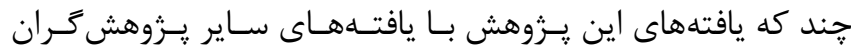

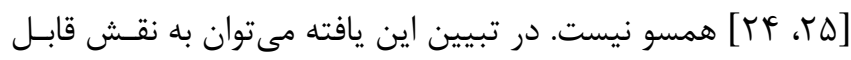

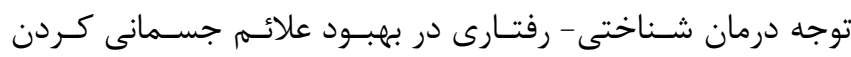

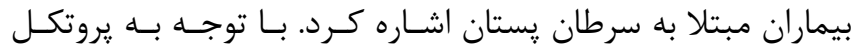

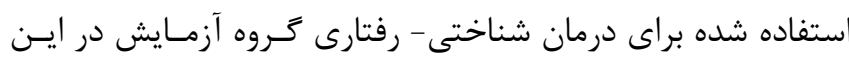

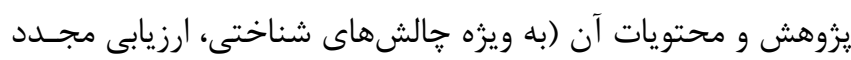

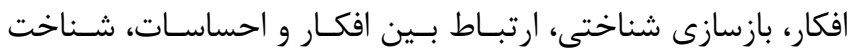

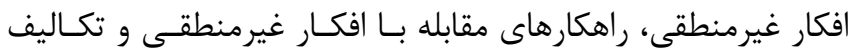

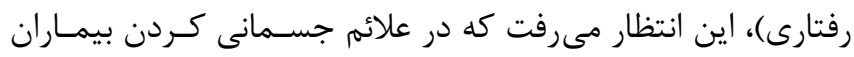
مبتلا به سرطان يستان بهبود حاصل شود؛ افرادى كـه داراى علائسم

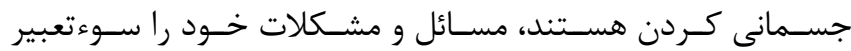

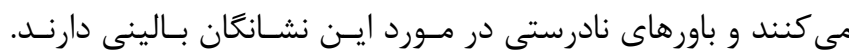

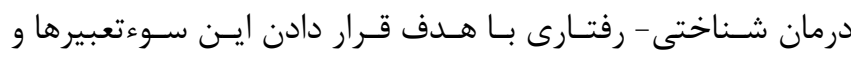
باورهاى نادرست موجب بهبود نشانهــاى بـالينى جسـمانى كـردن شركت كنندكان شده است.

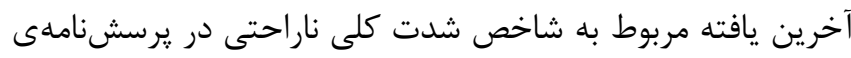

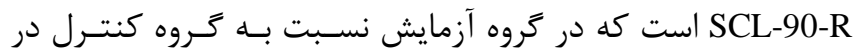

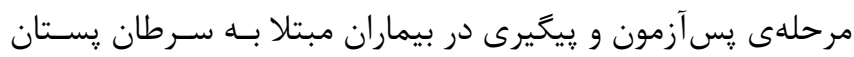

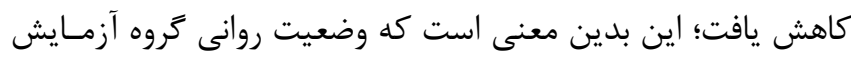

اشاره كرده كه اختلال فوبى درمان ويزه داشته و صرفاً با يـك روش

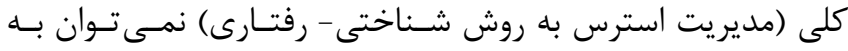

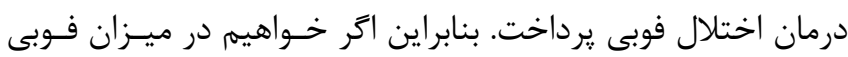
بيماران در مراحل مختلف درمان تفاوت معنادار ملاحظه كنسيه، بــهـ

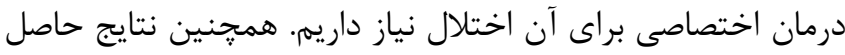

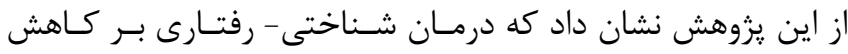

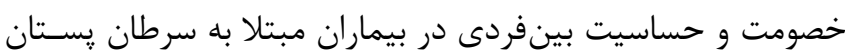

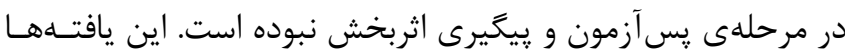

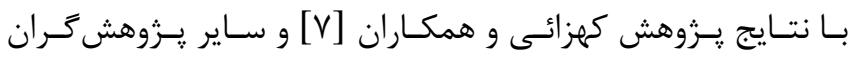

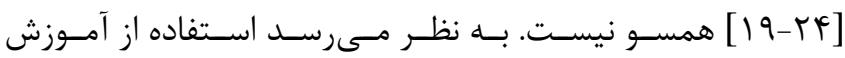

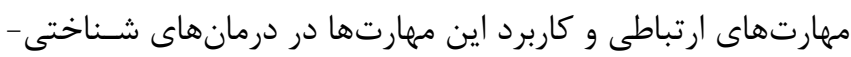

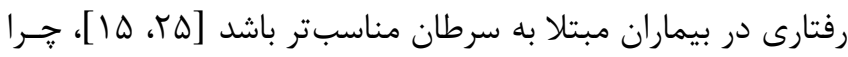

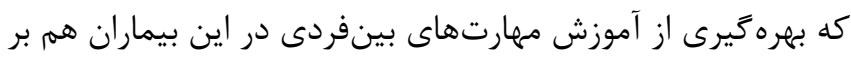

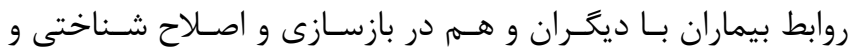

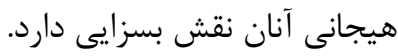

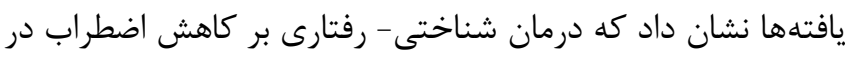

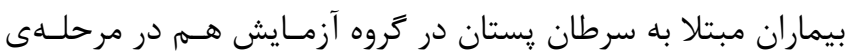
يسآزمون و هم در مرحلهى يُيگيرى نسبت به كروه كنترل اثربخش

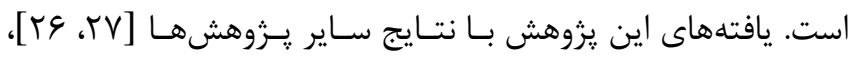

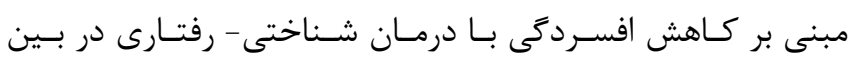

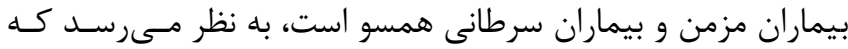

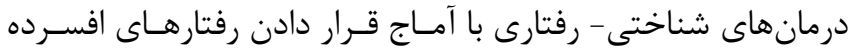

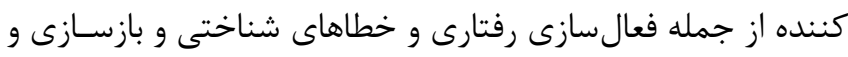
اصلاح شناختى در كاهش افسردگى بيماران سـرطانى مفيـد اسـت.

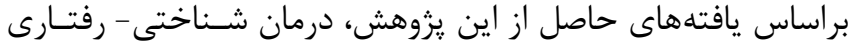

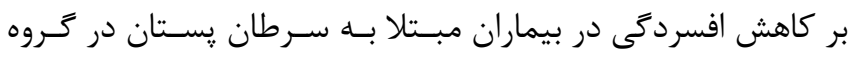

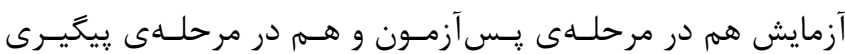

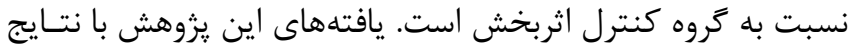

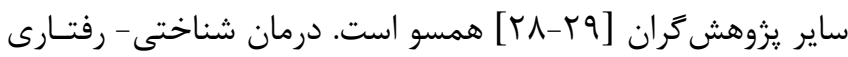

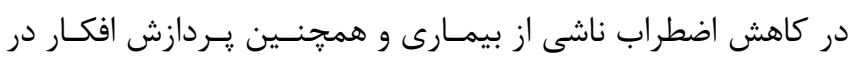

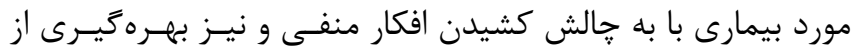

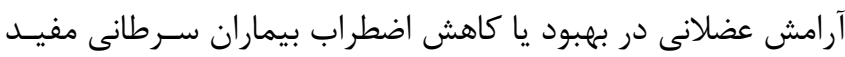

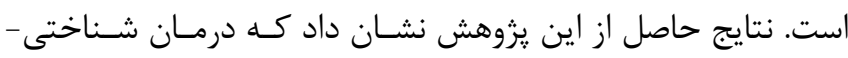
رفتارى بر كاهش وسواس- اجبار در بيماران مبتلا به سرطان يستان در مرحلهى يس آزمون و بِيخيرى اثربخش نبوده است. اين يافتـهـــا

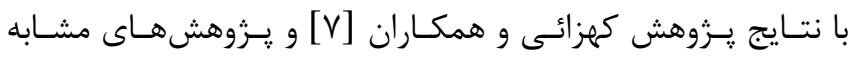


يروهش به آن اشاره شده است؛ عدم شركت منظهم برخى از شـركت

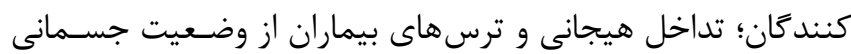

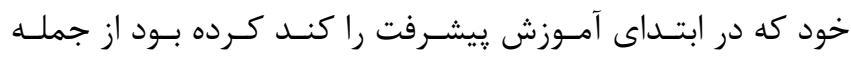

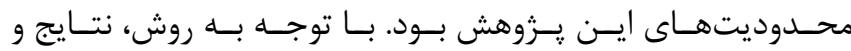
محدوديتهاى اين يزوهش، يُ ييشنهاد مى شود كه ساير يزوهش

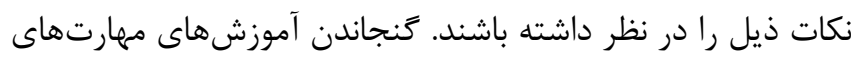

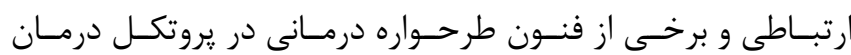

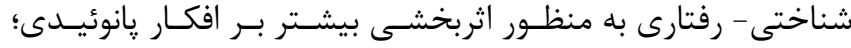

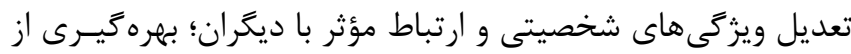

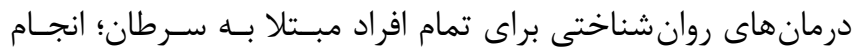

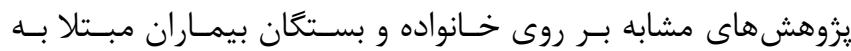

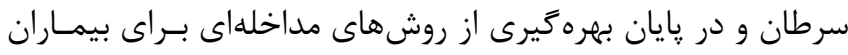

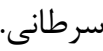

\section{سهم نويسند كان}

حميدرضا جميليان: استاد راهنما صفورا غفورى آثار: كردآورى دادههان اسناد راهنا

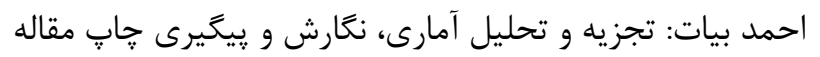

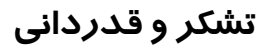

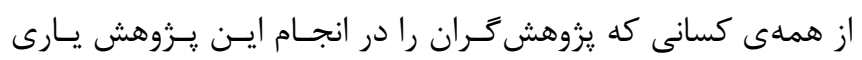

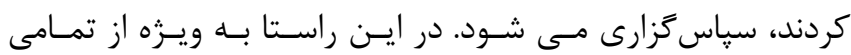

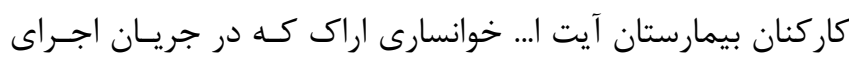

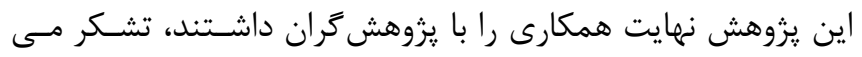

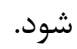

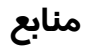

1. Mo'tamedi G. Human and Death; Introduction to Mrgshnasy. $1^{\text {st }}$ Edition, Tehran: Markaz Publication: Tehran, 2007 [in Persian]

2. Fukui S, Ogawa K, Yamagishi A. Effectiveness of communication skills training of nurses on the quality of life and satisfaction with healthcare professionals among newly diagnosed cancer patients. Psycho Oncology 2011; 20: 1285-91

3. Jamilian HR, Khansari MR, Safari V. Comparison of the efficacy of cognitive-behavioral therapy and communication skills with the patient to increase the patient's quality of family life. Urmia University of Medical Sciences. 2013; 24: 987-95 [in Persian]
با درمان شناختى - رفتارى بهبود يافته و به نظر مىرسد كه كـاربرد

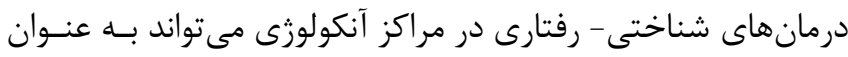

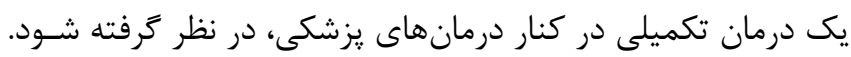

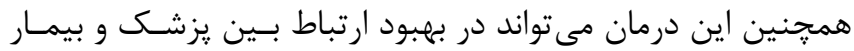

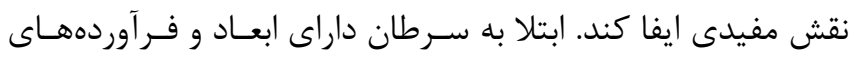

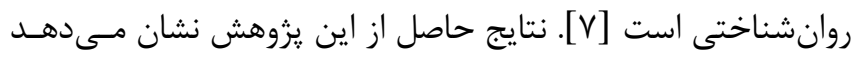

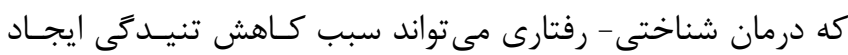

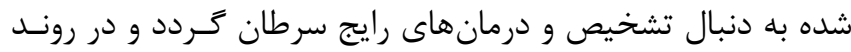

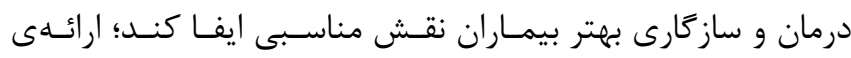

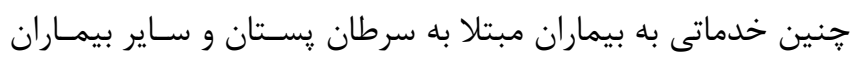

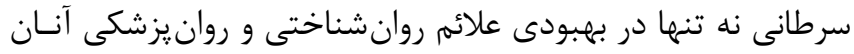

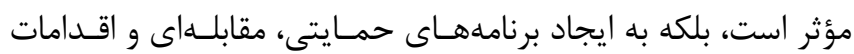

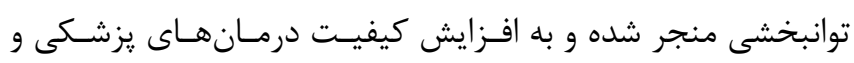

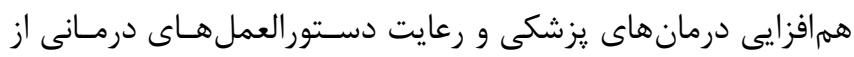

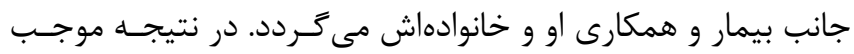

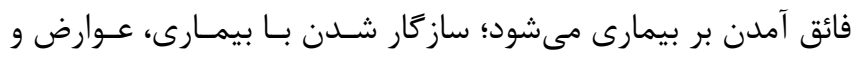

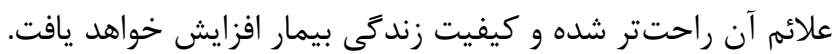
با توجه به يافتههاى اين يزوهش مى توان كفت كه كـاربرد مـديد

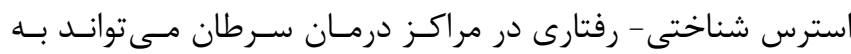

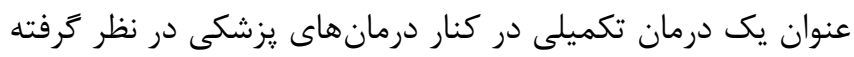

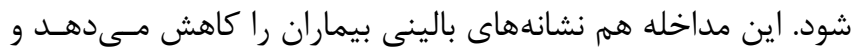

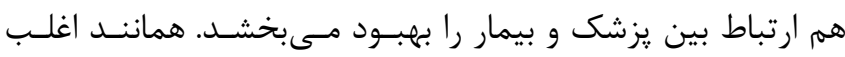

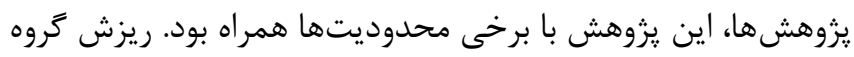

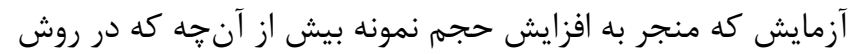

4. Canam C, Acorn S. Quality of life for family caregivers of people with chronic health problems. Rehabilitation Nursing 1999; 24: 192-200

5. Heimberg RG, Becker RE. Cognitivebehavioral group therapy for social phobia: Basic mechanisms and clinical strategies. $1^{\text {st }}$ Edition, New York: Guilford Press; 2002

6. Addington-Hall J, Lay M, Altmann D, McCarthy M. Symptom control, communication with health professionals, and hospital care of stroke patients in the last year of life as reported by surviving family, friends, and officials. Stroke 1995; 26: 2242-8 7. Kahzaei F, Danesh E, Heidarzadegan AR. Effectiveness of cognitive-behavioral therapy in 
reducing psychological symptoms in patients with cancer. Research in Medical Sciences 2012; 14: 112-6 [in Persian]

8. Linden W. Stress management: from basic science to better practice. $1^{\text {st }}$ Edition, London: Sage Publications, 2004

9. Bower JE, Segerstrom SC. Stress management, finding benefit, and immune function: positive mechanisms for intervention effects on physiology. Psychosomatic Research 2004; 56: 9-11

10. Bower JE, Kemeny ME, Taylor SE, Fahey JL. Finding positive meaning and its association with natural killer cell cytotoxicity among participants in a bereavement-related disclosure intervention. Annals of Behavioral Medicine 2003; 25: 146-55

11. Salehzadeh $M$, Kalantari $M$, Molavi $H$, Najafi MR, Nouri A. Effectiveness of cognitive-behavioral group therapy with focusing on dysfunctional attitudes in epilepsy on quality of life in intractable epileptic patients. Behavioral Sciences 2011; 4: 255-60 [in Persian]

12. Dunlop S. Cognitive behavioural therapy in palliative and end-of-life care. End of Life Care 2010; 4: $46-52$

13. Hopko D, Lejuez C. A cancer patient's guide to overcoming depression and anxiety: Getting through treatment and getting back to your life. $1^{\mathrm{s}} \mathrm{t}$ Edition, New Harbinger Publications, 2008

14. Sperry L. Handbook of diagnosis and treatment of DSM-IV personality disorders. Routledge; 2013 May 13. Translated by Khansari MR, Mojtabaei M, Jamiliyan HR, Ajlou M. $1^{\text {st }}$ Edition, Elm Publication: Tehran, 2013 [in Persian]

15. Anisi J, Eskandari M, Bahmanabadi S, Noohi S, Tavalayi A. Standardization of Symptom Checklist 90 Revised (SCL-90 -R) of a military Unit. Journal of military Psychology 2014; 5: 57-67 [in Persian]

16. Tanhaye Reshvanloo F, Saadati A. Construct validity and reliability of Symptom Checklist-25 (SCL-25). Fundamentals of Mental Health 2016; 18: 48-56 [in Persian]

17. Aeronson G, Antoni M, Sniderman N. A practical guide to managing stress in a cognitive-behavioral way. Translated by Ale-Mohammad J, Jokar S, Neshatdoost HT. $1^{\text {st }}$ Edition, Jahad-Daneshgahi Publications: Isfahan, 2010 [in Persian]
18. Ferry M. A Practical Guide to Cognitive Group Therapy. Translated by Mohammadi M, \& Farnam R. $1^{\text {st }}$ Edition, Roshd Publications; 2013 [in Persian]

19. Lechner SC, Antoni MH, Lydston $\mathrm{D}$, et al. Cognitive-behavioral interventions improve quality of life in women with AIDS. Psychosomatic Research 2003; 54: 253-61

20. Penedo FJ, Dahn JR, Molton I, et al. Cognitive behavioral stress management improves stress management skills and quality of life in men recovering from treatment of prostate carcinoma. Cancer 2004; 100: 192-200

21. Penedo FJ, Traeger L, Dahn J, et al. Cognitive behavioral stress management intervention improves quality of life in Spanish monolingual Hispanic men treated for localized prostate cancer: results of a randomized controlled trial. Behavioral Medicine 2007; 14: 164-72

22. Cooper CL. Stress and Coping with it. Translated by Gharachdaghi M. \& Shariatzadeh N. $1^{\text {st }}$ Edition, Roshd Publication: Tehran, 1996 [in Persian]

23. Basharpoor S, Molavi P, Sheikhi S. Comparison of marital satisfaction and quality of life in people with obsessive-compulsive disorder and other anxiety disorders and normal people. Urmia Medical Journal 2013; 23: 597-605 [in Persian]

24. Distefano M, Riccardi S, Capelli G, et al. Quality of life and psychological distress in locally advanced cervical cancer patients administered pre-operative chemoradiotherapy. Gynecologic Oncology 2008; 111: $144-50$

25. Mohammadian Akerdi E, Asgari P, Hassanzadeh R, Ahadi H, Naderi F. Effects of cognitive-behavioral group therapy on increased life expectancy of male patients with gastric cancer. Journal of Babol University of Medical Sciences 2018; 20: 28-32 [in Persian]

26. Hamid N, Talebian L, Mehrabizadeh Honarmand M, Yavari AH. Effectiveness of logotherapy on depression, anxiety and quality of life patients with cancer. Psychological Achievements 2011; 4: 199-224 [in Persian]

27. Pedram M, Mohammadi M, Naziri Q, Aeinparast N. Effectiveness of cognitive-behavioral therapy in the treatment of anxiety disorders, depression and create hope for women with breast cancer. Woman and Society 2010; 1: 61-76 [in Persian] 
28. Iesazadegan A, Sheikhi S, Hafezniya M, Khademi A. Effectiveness of cognitive-behavioral group-therapy in reducing symptoms of depression among patients with cancer. Urmia Medical Journal 2013; 24: 239-46 [in Persian]
29. Khodaei S, Dastjerdi R, Haghighi F, Saadatjoo AR, Keramaty E. Efficiacy of cognitive-behavioral group-therapy on depression in patients with cancer. Journal of Medical Sciences University of Birjand 2011; 18: 183-90 [in Persian] 